\title{
Determinants of rural household financial literacy: Evidence from south india
}

\author{
M. Jayanthi* and S.S. Rau \\ Research Scholar, Sathyabama University, and Registrar, Sathyabama University, Chennai, India
}

\begin{abstract}
The purpose of this paper is to investigate the study of rural household's financial literacy. Financial literacy is understood as the set of knowledge, attitudes, and behaviors, which has assumed a fundamental role in allowing and enabling people to make responsible decisions as they strive to attain financial wellbeing. In this research, the researcher throws a descriptive research design to explore the relationship between variables. Respondents were obtained from 126 households in rural areas of Tamil Nadu and data was collected using the stratified sampling method. The current study found that education, marital status, type of family and banks relationship were positively related to financial literacy. However, age, gender, occupation, and No.of dependents are not significantly correlated with financial literacy. There is a positive association between financial literacy and banks, banks must actively involve in re-designing educational programs, workshops, training methods on financial issues for all the levels of people in rural areas. It is believed that such a step taken forward will help banks in helping people reach a better financial condition.
\end{abstract}

Keywords: Financial literacy, demographic variables, rural household, Tamil Nadu

\section{Introduction}

Financial literacy is a big challenge for the rural population in India. It also plays a key role in the economic prospects. In India, many poor people do not have a bank account and only a few of them understand the concept of financial literacy. Poverty eradication and financial literacy are two main initiatives for the central government to uplift the economic development in such areas. India's economic growth rate was $8 \%$ in the year 2014-2015 and which is one of the fastest growing economies in the world, still financial literacy is low compared to other countries. In the Master card survey [25] report shows that the overall financial literacy index rate in India was 62 points lower comparing other countries. Financial Knowledge means the ability to deal with everyday financial matters and make the right choice in spending, borrowing, budgeting, savings and investment decisions. Financial literacy is an

*Corresponding author: M. Jayanthi, Department of Management Studies, Sathyabama University, Rajiv Gandhi Road, Chennai-119, India. Tel.: +91 9443070037; E-mail: go2jyth@yahoo.co.in. ability to make an informed choice and to take effective action regarding the money [6]. Financial literacy is the ability to understand money and how to manage it, so that person can make better financial decisions, (US Department of Treasury). Low and moderate income families lack the basic knowledge to save, many families spend beyond their means few of them save enough for contingencies [11].

Financial literacy helps in assessing individuals financial position, the economic situation in less stress level and financial issue [13]. People with a low level of financial literacy are more likely to have problems with financial behavior with debt [16]. Cole et al. [9] investigated the level of financial knowledge among rural respondents in India and Indonesia. There were 4860 respondents, from India and Indonesia. They were tested on behavior and knowledge of the respondent's financial issues which should be understood in order to function in everyday life. The highest test score was achieved by Indonesia (52\%) and India (34\%) of rural respondents. The average score was $42 \%$ for all the respondents. They found that rural area female household and farm owners demonstrated the lowest level of 
financial literacy. In the context of such prevalent financial illiteracy and increasing need for enhanced financial understanding, it has become vital to evaluate not only the current level of financial literacy among the rural population but also to examine its determinants, as it strength helps to formulate policy interventions. This study appears to be one of its kind in south India.

\section{Review of literature}

There has been an increasing importance in the financial knowledge of academic society, international organizations and the government recently [18]. However, in many developing countries, rural population find themselves expelled from the formal financial sector [10]. In addition to this rural population possess a high level of basic financial illiteracy. This paper examines the relationship between a level of financial literacy of rural population in south India and its determinants.

According to Worthington [3], He found that in their study financial literacy was highest for persons aged between 50 to 60 years in all professionals like business people and farm owners. As well as financial literacy were lowest for the unemployed persons, females, and those who non-English speaking background and low level of education.

Lusardi et al. [4] examined that financial literacy was low among young individuals. Only one-third of young adults possess basic knowledge of inflation, interest rate, and risk diversification. Financial literacy was strongly related to family sophistication and sociodemographic characteristics [23]. In their study determined the financial literacy of 100 micro entrepreneurs in Davao city. In their study, it was found that financial literacy of micro-entrepreneurs was just moderate and the report revealed that educational level was significantly influenced on the financial literacy. According to their study gender cannot predict the level of financial literacy. Moreover, the entrepreneurs were not sophisticated in saving, budging, and record keeping and financing, they were not utilizing their skills. Chen and Volpe [8] found that women had lower enthusiasm, confidence, willingness, and knowledge about personal finance Furthermore, their research found that education and experience had a significant impact on the financial literacy of both Men and women. In addition to that studies revealed that most of the respondents not willing to learn financial knowledge through formal education rather than informal channels. Agarwalla [21] study investigated the influence of various socio-demographic factors on the different dimensions like attitudes, behavior, knowledge of financial literacy. The study found that gender, education, joint family, consultative decision, and income are found to significantly influence financial literacy. Also, the reports revealed that the young respondents had poor financial behavior which leads to the absence of self-control in money management skills. Ansong and Gyensare [1] the report explores the determinants of financial literacy of 250 undergraduate and postgraduate university working students in Ghana. The study found that age, work experience, and mother's education of the university students were positively related to financial literacy. However work location, level of study, father's education of the respondents, access to media and source of education on money were not correlated with financial literacy. Tamimi and Kalli [14] examined their study and found that there is a relationship between financial literacy and factors that affect investment decision of 290 UAE national investor. The results showed that the financial literacy of UAE investors was very less when compared to the expected level. The financial literacy level was found to be affected by income, education level, and workplace activity and gender. Atakora [5] did an in-depth study in measuring the effectiveness of financial literacy programs of 235 petty traders in Ghana. This study also found that the work experience, age, mothers education of the respondents and education were positively correlated with financial literacy. There was a huge financial literacy gap between educated traders and uneducated traders. The report suggested that policymakers should make sure that customers get easily get access to the bank activities related to financial education. Ravikumar et al. [19] an in-depth study was conducted in financial literacy among 200 jasmine farmer in Tamilnadu province. The study revealed that age, education, income, relationship with the bank, bank visit and bank account and size of landholding were positively correlated to financial literacy. The farmers with higher income, higher educational status and maintain long years of relationship with the bank have higher financial literacy. The farmers those who received financial management training program had higher financial literacy. According to Scheresberg [7] the study demonstrated the financial literacy and financial behavior of 4500 young adults. This study throws light information that young adults lack basic financial knowledge. Furthermore, Financial literacy was low among demographic groups, 
Table 1

Means, standard deviation, and correlations among demographic variables and financial literacy

\begin{tabular}{|c|c|c|c|c|c|c|c|c|c|c|c|c|c|}
\hline & Mean & $\mathrm{SD}$ & 1 & 2 & 3 & 4 & 5 & 6 & 7 & 8 & 9 & 10 & 11 \\
\hline 1. Age & 2.10 & 1.09 & 1 & & & & & & & & & & \\
\hline 2. Gender & 1.37 & 0.48 & $-0.164^{*}$ & 1 & & & & & & & & & \\
\hline 3. Marital Status & 1.79 & 0.50 & $0.475^{* *}$ & $0.224^{*}$ & 1 & & & & & & & & \\
\hline 4. Education & 2.81 & 1.16 & $-0.403^{* *}$ & $0.198^{*}$ & -0.158 & 1 & & & & & & & \\
\hline 5. Occupation & 2.0 & 1.05 & $-0.183^{*}$ & $0.375^{* *}$ & 0.000 & $0.181^{*}$ & 1 & & & & & & \\
\hline 6. No.of Dependents & 1.92 & 0.76 & -0.105 & $-0.218^{* *}$ & -0.053 & -0.168 & $-0.178^{*}$ & 1 & & & & & \\
\hline 7. Family Size & 3.04 & 2.36 & 0.083 & 0.033 & $0.245^{* *}$ & -0.144 & -0.021 & $0.336^{* *}$ & 1 & & & & \\
\hline 8. Type of family & 3.18 & 2.63 & -0.011 & -0.143 & $0.293^{* *}$ & -0.007 & $-0.185^{*}$ & $0.425^{* *}$ & $0.131^{*}$ & 1 & & & \\
\hline $\begin{array}{l}\text { 9. Relationship with } \\
\text { Bank }\end{array}$ & 3.49 & 1.25 & $0.235^{*}$ & $0.245^{* *}$ & -0.113 & $-0.380^{* *}$ & 0.036 & $0.158^{*}$ & 0.000 & $-0.294^{* *}$ & 1 & & \\
\hline 10. Bank Visit & 2.95 & 1.34 & $-0.145^{*}$ & -0.060 & $-0.293^{* *}$ & -0.179 & $0.172^{*}$ & -0.115 & $0.199^{*}$ & $0.187^{*}$ & $0.209^{*}$ & 1 & \\
\hline 11. Financial literacy & 4.52 & 1.18 & -0.020 & 0.001 & $0.264^{* *}$ & $0.229^{* *}$ & 0.086 & 0.093 & $0.205^{* *}$ & $0.294^{* *}$ & $0.192^{*}$ & $-0.236^{*}$ & 1 \\
\hline
\end{tabular}

Notes: $\mathrm{N}=226$; Correlation is significant at ${ }^{*} p<0.05 ;{ }^{* *} p<0.01$, all two-tailed test.

such as women, minorities, and lower income and less educated people. However, a high level of education was not guaranteed to Financial Literacy.

\section{The hypothesis of the study}

Based on the literature reviewed, the following hypotheses are formulated.

H1: Financial literacy levels are significantly different with respect to age, Education, Family Size and Bank visit.

$\mathrm{H} 2$ : Financial literacy levels are significantly different with respect to gender, marital status, Occupation and type of family.

H3: Financial literacy levels are significantly different from their demographic variables.

\section{Method}

This study adopted a descriptive research design as a framework because it is appropriate when attempting to examine the relationship between variables. Respondents were selected using a stratified sampling method from the rural area in the year Jan-March 2018. The sample used in this study consisted of 126 rural area household respondents. Questionnaire as an instrument was used for the data collection. Cronbach's Alpha was done to the reliability of the data.

\section{Measure}

Apart from respondents demographic characteristics, 6 multiple choice variables where included in the questionnaire for collecting the data. Descriptive statistics including mean, standard deviation together with Karl Pearson product moment correlation were used to set up the relationship between demographic characteristics and rural household financial literacy. Independent samples t-test was used to study the differences in financial literacy based on respondents gender, the status of marriage, occupation, and type of family. Again, One-way analysis of variance (ANOVA) was used to analyze the variations in rural household financial literacy across their age, Education, family size, Depdendent Members and Bank visit. Analysis of data in this study was done using SPSS statistics, version 22.0 at the 0.05 level of significance.

\section{Results and Discussion}

The means, standard deviations are intercorrelations for the determinants of financial literacy used in this research are detailed in Table 1 . In terms of demographic variables, Education $(r=0.229, p<0.01)$ and Family size $(r=0.205, p<0.01)$ were positively correlated with the financial literacy of respondent's. This supports the evidence of Scheresberg [7], Sucuahi [23], Chen and Volpe [8], Tamimi and Kalli [14] and Atakora [5]. In Indian context size of the family plays an important role for determinants of financial literacy. Moreover, the size of the family increased the knowledge of financial issues also increases. Furthermore, the study reveals that socio-economic variables such as Marital status $(r=0.264, p<0.01)$ and type of family $(r=0.294, P<0.01)$ also positively correlated to financial literacy. The influence of the joint family and advice given by the older family members on financial decision-making may improve the financial knowledge [21]. Banking connectivity variables 
Table 2

T-test analysis of differences in financial knowledge based on demographic variables

\begin{tabular}{lccccc}
\hline Variables & $\mathrm{N}$ & Mean & $\mathrm{d}$ & $\mathrm{ft}$ & $\mathrm{P}$ \\
\hline Gender & & & & & \\
$\quad$ Male & 74 & 1.36 & 124 & 0.008 & $0.993^{\dagger}$ \\
$\quad$ Female & 52 & 1.37 & & & \\
$\quad$ Status of marriage & & & & & \\
$\quad$ Single & 37 & 1.50 & 124 & 3.05 & $0.003^{*}$ \\
$\quad$ Married & 89 & 1.98 & & & \\
Occupation & & & & & \\
$\quad$ Organised sector & 34 & 2.09 & 86 & 2.81 & $0.074^{\dagger}$ \\
$\quad$ UnOrganised sector & 54 & 2.00 & & & \\
$\quad$ Type of family & & & & & \\
$\quad$ Joint & 50 & 3.89 & 124 & 3.45 & $0.001^{*}$ \\
$\quad$ Nuclear & 76 & 3.09 & & & \\
\hline
\end{tabular}

$\mathrm{N}=226 ;{ }^{*} p<0.05$ (significant); ${ }^{\dagger} p .0 .05$ (Not significant).

such as the relationship with the bank $(r=192, p<$ $0.05)$ and the number of bank visit in a year $(r=0.236$, $p<0.01)$ were positively correlated with the financial literacy. The respondents who visited bank many times in a year had higher financial literacy were compared to others [19]. However, Age $(r=-0.020, p>$ $0.05)$, Gender $(r=00.001, p>0.05)$, occupation $(r=$ 0.086, $p>0.05)$, and No of dependents $(r=0.093$, $p>0.05)$ were all not significantly correlated with respondents financial knowledge.

Table 2 reveals that a significant difference exists between financial literacy and the marital status of respondents $(t=4.27, p<0.05)$. Cole et al. [9] found that unmarried respondents are not interested in financial literacy program it leads to low financial knowledge. The findings show that the joint family demonstrates the higher level of financial literacy than the nuclear family $(t=3.45, p<0.01)$. Furthermore, the study reveals that male and female $(t=3.45, p<$ 0.01 ), in organized sector and unorganized sector respondents, are just having average or equal knowledge about financial issues. This result contradicts Guisob and Jappelli [15] and Goldsmith R. and Goldsmith E. [20] being men having greater financial knowledge. Women score less than men because in general, they are less interested in financial services and personal finance.

In order to determine whether there is a significant difference between demographic variables and financial literacy of the respondents, One-way analysis of variance (ANOVA) with Duncan post-hoc test was conducted as the shown Table 3. Financial literacy of rural household was equal among all age groups, $(F=$ $1.83, P>0.15)$. The post hoc analysis revealed that respondents with all age group members have equal knowledge invariably of different years. These findings
Table 3

One-Way ANOVA analysis of demographic variable comparison on financial knowledge

\begin{tabular}{lrrrrc}
\hline Variables & $\mathrm{N}$ & Mean & df & $\mathrm{F}$ & $\mathrm{P}$ \\
\hline Age & & & & & \\
20-30 & 42 & 1.85 & 125 & 1.83 & $0.15^{\dagger}$ \\
$31-40$ & 38 & 1.93 & & & \\
$41-50$ & 28 & 1.57 & & & \\
50 above & 18 & 2.00 & & & \\
Education & & & & & \\
$\quad$ Primary & 20 & 2.13 & 125 & 4.52 & $0.001^{*}$ \\
$\quad$ High school & 32 & 2.36 & & & \\
Higher secondary & 26 & 3.01 & & & \\
Grauate above & 40 & 3.98 & & & \\
Dependent members & & & & & \\
$\quad$ 2 & 36 & 1.83 & 125 & 0.93 & $0.316^{\dagger}$ \\
3-4 & 70 & 1.77 & & & \\
4-6 & 14 & 1.86 & & & \\
Above 6 & 6 & 2.33 & & & \\
Family size & & & & & \\
1-2 & 24 & 2.31 & 125 & 3.95 & $0.003^{*}$ \\
3-4 & 64 & 2.89 & & & \\
5 Above & 38 & 3.97 & & & \\
Bank visit & & & & & \\
Monthly & 36 & 3.96 & 117 & 4.89 & $0.000^{*}$ \\
Quarterly & 28 & 3.15 & & & \\
Halfyearly & 26 & 2.71 & & & \\
Yearly & 36 & 2.00 & & & \\
\hline
\end{tabular}

$\mathrm{N}=226 ;{ }^{*} p<0.05$ (significant) $;{ }^{\dagger} p .0 .05$ (Not significant).

were contradicted to the study of Ansong and Gyensare [1] wherein the students with different age had the significant difference in financial literacy. Financial literacy is strongly related to socio-demographic characteristics and family sophistication [4]. However, education $(F=4.12, P<0.001)$ attainment is measured to be an imperative demographic variable as it would influence the ability to make a decision. The person who holds high educational degrees has higher financial literacy level than others [2,17]. A higher level of education has the higher level of financial knowledge. Moreover, Type of family $(F=3.95, P<0.003)$, and No. of Bank visit $(F=4.89, P<0.000)$ has the significant difference in rural household respondents, the source of education on money.

\section{Conclusion}

The research found that demographic variables are highly positively related towards the financial literacy. We have found that Education and marital status are positive predictors of respondents financial literacy. A higher level of education leads to good in financial literacy [24]. Also, family size and type of family is positively related to financial literacy. This confirms find- 
ings of previous study by Agarwalla [21]. This means that one critical source of information and education on the financial issue for the rural respondents is family. However, Age, Gender, occupation, and Dependent family members were all not significantly correlated with financial literacy. The findings showed that male and female rural household respondents demonstrate an equal level of financial literacy. The gender is not a significant factor among rural household respondents [22]. Once again we found that significant difference exists between financial literacy of joint family and Nuclear family. The findings indicate that joint family respondents display a higher level of financial literacy than Nuclear family respondents. The findings, therefore, shows the effect of family education were higher financial knowledge. This supports the previous study by Lusardi et al. [4] financial literacy was strongly correlated with family sophistication.

Given that there is a positive relationship between No. of Bank visit and financial literacy, the study shares the recommendation that Bank must actively involve in re-designing such educational programs, workshops, training on financial issues at all level of people in rural areas. The study concluded that retaining more years of relationship with the Bank would have higher financial literacy [19]. The financial literacy have a cause on an opening bank account for the people, even though it has an impact on those with the low level of education and financial literacy [9]. This study result reveals that Low level of financial literacy leads to poor financial behavior such as money management, investment and borrowing skill of rural household individuals. The study confirmed that south India rural area respondents have minimum and less knowledge about financial issues. The study recommends the government should concentrate regularly and monitor on improvements of financial knowledge of the rural area to enhance the financial literacy viva upliftment of such region so that it will help in the economic development of our country in long run.

\section{Acknowledgments}

We thank the editor and an anonymous referee for helpful comments. The findings and conclusions in the paper are those of the authors and gratitude to Tamil Nadu rural households for the cooperation, especially the villagers who participated in this study.

\section{References}

[1] Ansong, A. and Gyensare, M.A. Determinants of university working-students financial literacy at the University of gape coast, Ghana. International Journal of Business and Management. 2012; 7: 126-133.

[2] Agnew, J.R. et al. Financial literacy and retirement planning in Australia. doi://dx.doi.org/10.5038/1936-4660.6.2.7.2; 2013; 6: 1-25

[3] Worthington, A.C. Predicting financial literacy in Australia. Financial Services Review. 2006; 15: 59-79.

[4] Lusardi, A. et al. Financial literacy among young. Michigan Retirement Research Center Working Paper No. Wp 2008$191 ; 2009$.

[5] Atakora, A. Measuring the effectiveness of financial literacy programs in Ghana. International Journal of Management Business Research. 2013; 3: 135-148.

[6] Basu, S. Financial Literacy And The Life Cycle. White House Conference On Aging [homepage on the Internet] 2005; [Updated 2005 April; Cited 2014 Jan] Available from http// member/govt_relation/new/loader.cfm?url=/commonspot/ security/getfile.cfm\&PageID=33231.pdf.

[7] Scheresberg, C.B. Financial Literacy and Financial behavior among Young Adults: Evidence and Implications, doi://dx. doi.org/10.5038/1936-4660.6.2.5. 2013; 6: 5 .

[8] Chen, H. and Volpe, R.P. Gender differences in personal financial literacy among college students. Financial Services Review. 1997; 11: 289-307.

[9] Cole, S. et al. Prices or Knowledge? What Drives Demand for Financial Services in Emerging Markets. Harvard Business School Working paper No. 09-117; 2009.

[10] Nguyen, C.H. Access to credit and borrowing Behaviour of Rural Households in a transition. International Conference on Rural Finance [homepage on the Internet] Research. 2007; [Updated 2007 April; Cited 2018 Jan] Available from http://www.fao.org/ag/rurfinconference/docs/papers_theme_ 1/access_credit.pdf.

[11] Bell, E. and Lerman, R.I. Can Financial Literacy Enhance Asset Building. An Urban Institute Project Exploring Upward [homepage on the Internet] Mobility. 2005 [Updated 2005 April; Cited 2017 Sep]. Available from www.Urban.Org/ Uploadedpdf/311224_Financial_Literacy.pdf.

[12] GIZ. Agriculture Rural financial programme. German Federal Ministry for economic corporation and [homepage on the Internet] development Uganda. 2014: [Updated 2014 April; Cited 2017 Nov] Available https://www.giz.de/en/worldwide/ 19361.htm.

[13] Jariwala, H. and Sharma, M. Financial Literacy. International Journal Of Academic Conference Proceedings. [homepage on the Internet]: 2006. [Updated 2011 April; Cited 2017 Dec] Available from, http://www.ijacp.org/ojs/index.php/ISG/ article/view/17/20.

[14] Tamimi, H.A. and Kalli, A.B. Financial literacy and investment decisions of UAE investors. The Journal of Risk Finance. 2009; 10: 500-516.

[15] Guisob, L. and Jappelli, T. Financial literacy, and portfolio diversification. European University Institute. Working Paper No. ECO2008/31; 2008.

[16] Lusardi, A. and Tufano, P. Debt Literacy, Financial Experiences, And Overindebtedness, NBER Working Paper No. 14808; 2008.

[17] Mandell L. Financial literacy of high school students: Xiao, J.J. ed. Handbook of Consumer Finance Research. New York: Springer; 2008: 163-183. 
[18] Olga, K. Financial literacy in Ukraine: Determinants and implication for saving behavior. Master Thesis. 2011; Available from http://www.kse.org.ua/uploads/file/library/MAThesis 2011/KHARCHENKO.pdf.

[19] Ravikumar, R. et al. Assessment of farm Financial literacy among Jasmine growers in Tamilnadu India. Developing Country Studies. 2013; 3: 67-75.

[20] Goldsmith, R.E. and Goldsmith, E. The effect of Investment education on gender difference in financial knowledge. Research and Theory. 2006; 5: 55-69.

[21] Agarwalla, S.K. Financial literacy among working young in urban India. IIMA Working paper No.2013-10-02; 2003.
[22] Wagland, S.P. and Taylor, S. When it comes to financial literacy, is gender really an Issue? Australian Accounting Business and Finance Journal. 2009; 3: 13-25.

[23] Sucuahi, W.T. Determinants of Financial literacy of MicroEntrepreneurs in Davao City. International Journal of Accounting Research. 2013; 1: 44-51.

[24] Zaimah, R. et al. Financial behaviors of female teachers in Malaysia, Asian Social Science. 2013; 9: 34-41.

[25] Master Card Survey. Master card financial literacy Index Report. [homepage on the Internet]: 2015. [Updated 2015 April; Cited 2017 Sep] www1.mastercard.com/content/intelligence/ en/research/reports/2015/mastercard-financial-literacy-indexreport-2014h1.html. 